\title{
Morphological and physiological variation among different isolates of Alternaria spp. from Rapeseed- Mustard
}

\author{
Rufaida Monowara ${ }^{1}$, Nazmoon Naher Tonu ${ }^{1,2^{*}}$, Fatema Begum ${ }^{1}$, Md. Masud Karim ${ }^{2}$, \\ Nazneen Sultana ${ }^{1}$
}

\author{
${ }^{1}$ Department of Plant Pathology, Sher-e-Bangla Agricultural University, Dhaka, Bangladesh \\ ${ }^{2}$ Saskatoon Research and Development Centre, AAFC, 107 Science Place, SK, Canada
}

\begin{abstract}
To find out the Morphological variation on growth and sporulation of Alternaria species of Alternaria leaf blight of mustard from 10 representative geographical locations of Bangladesh, this experiment was conducted at Plant Pathology Laboratory, Oilseed Research center, Bangladesh Agricultural Research Inistitute (BARI), Joydevpur, Gazipur, Bangladesh. All the isolates showed high level of variability in in-vitro in respect of radial mycial growth, colony colour, sub surface colour, colony shape, colony texture, zonation (surface and sub surface), length and width of conidia, beak length and number of septa. The maximum and minimum radial mycial growth was recorded $90 \mathrm{~mm}$ in isolate $N A T_{A b}$ and $83.67 \mathrm{~mm}$ in isolate $G A Z_{A b}$, respectively at 14 days after incubation. Significant variation in conidial length, width, beak and no. of conidia observed in all isolates. The length of conidia ranged from 41.56 to $117.54 \mu \mathrm{m}$ with 3 to 11 transverse and 0 to 3 vertical septa. The width and beak length varied from 10.34 to $23.12 \mu \mathrm{m}$ and 16.78 to $72.65 \mu \mathrm{m}$, respectively. Surface colour were olivacious green to black and circular shaped colonies were observed in all isolates on PDA medium. Colony texture were cottony to velvety. Subsurface colour varied from light brown to black and pinkish. Zonation found in some isolates and some did not produce on both surface and subsurface. All conidia were murifrom and light brown to deep brown in colour. Potato Carrot Dextrose Agar medium (PCDA) and $25^{\circ} \mathrm{C}$ temperature were found optimum for different isolates for mycelial growth and sporulation.
\end{abstract}

Keywords-Alternaria brassicae, mustard, morphology, physiology, culture media, variability.

\section{INTRODUCTION}

Rapeseed-Mustard (Brassica spp.) is the principal oilproducing crop of Bangladesh yielding $77.51 \%$ [4] of total oilseed production from $60.3 \%$ of the total area coverage. This crop is cultivated, at present, in about 802882 acres. The production is about 359452 lac metric tons oil [4]. The average yield of mustard is $447 \mathrm{Kg} / \mathrm{ha}$. Total production and per hectare seed yield of this crop may be increased by using high yielding variety (HYV) and improved production technologies.

Rapeseed-mustard is cultivated almost all over the world. It is grown in tropical as well as temperate agro climatic zones and are the best adapted to areas having a relatively cool, moist climate during the growing season. [18]. Alternaria leaf blight caused by Alternaria brassicae is one of the major diseases of mustard $[21,29,15,1,10,37,7]$. This disease reduces mustard yield up to $47 \%$ [30] in India. It is a prominent disease in India, Australia, Canada, Africa, England, Germany, France, Sri Lanka, Spain and Sweden, all most all around the world [12].

Around the initial site of host leaf Alternaria morphologically produces a series of concentric rings [2]. A. brassicae is a necrotrophic pathogen produce lesion on leaves, stem and siliquae which affect seed quantity, quality by reducing oil content, seed size and seed colour [8]. This disease may cause significant losses in both temperate and tropical Brassica crops [20].

The major aspects of biology of an organism are the morphological and physiological characters of an individual within a species. Although, it is not frequent in asexually produced individual of the progeny. Variability studies are important to document the changes occurring in populations and individuals as variability in morphological and physiological traits indicate the existence of different pathotypes [21]. Anamorph form of this pathogen shows great variability in morphology, physiology and pathogenicity. Several researchers have reported existence 
of variability based on morphology, sporulation, growth and cultural characteristics.

We know, every pathogen species has numerous biotypes, races or pathotype with specific genes in the respective host plants [36]. Proper understanding in the variation of pathogen population is highly crucial in the process of breeding for resistance against a particular disease.

Considering the above fact this research was undertaken to Find out the morphological and physiological variation among different isolates of Alternaria spp.

\section{MATERIALS AND METHODS}

The experiment was conducted in the Plant Pathology Laboratory, Oil Seed Research Center, Bangladesh Agricultural Research Institute (BARI), Joydevpur, Gazipur, Bangladesh during the period from July 2015 to March 2016.

\subsection{Collection of leaf sample}

Mustard leaves having typical symptoms were collected from 10 mustard growing districts of Bangladesh namely Dhaka, Rajshahi, Natore, Naogaon, Bogra, Lalmonirhat, Gazipur. Rangpur, Pabna and Mymenshingh.

\subsection{Designation of collected isolates}

The collected isolates were designed as $\mathrm{DHA}_{\mathrm{Ab}}, \mathrm{GAZ}_{\mathrm{Ab}}$, $\mathrm{MYM}_{\mathrm{Ab}}$ based on their collected location. For example an isolate collected from Dhaka and recognized as first three letters of the area and $\mathrm{Ab}$ indicate Alternaria brassicae (Table 1).

Table.1: Designation of collected isolates of Alternaria

\begin{tabular}{lcl} 
District/Thana & $\begin{array}{c}\text { Istassicae } \\
\text { designation }\end{array}$ & Village/Place \\
\hline $\begin{array}{l}\text { Dhaka (SAU) } \\
\text { Gazipur (BARI) }\end{array}$ & $\begin{array}{l}\mathrm{DHA}_{\mathrm{Ab}} \\
\mathrm{GAZ}_{\mathrm{Ab}}\end{array}$ & $\begin{array}{l}\text { Agronomy field } \\
\text { Oil Research } \\
\text { field }\end{array}$ \\
Mymensingh & $\mathrm{MYM}_{\mathrm{Ab}}$ & Horticulture \\
(BAU) & & field \\
Pabna & $\mathrm{PAB}_{\mathrm{Ab}}$ & Bhabarhat \\
Rangpur & $\mathrm{RAN}_{\mathrm{Ab}}$ & Tillalpara \\
Natore & $\mathrm{NAT}_{\mathrm{Ab}}$ & Dayarampur \\
Naogaon & $\mathrm{NAO}_{\mathrm{Ab}}$ & Kamalpara \\
Lalmonirhat & $\mathrm{LAL}_{\mathrm{Ab}}$ & Benupara \\
Bogra & $\mathrm{BOG}_{\mathrm{Ab}}$ & Munail \\
Rajshahi & $\mathrm{RAJ}_{\mathrm{Ab}}$ & Khorkhori \\
\hline
\end{tabular}

SAU $=$ Sher-e- Bangla Agricultural University
BAU = Bangladesh Agricultural University

BARI = Bangladesh Agricultural Research Institute

\subsection{Preparation of PDA medium}

Potato dextrose agar (PDA) were prepared by $200 \mathrm{gm}$ potato extract, $1000 \mathrm{ml}$ distilled water, $17 \mathrm{gm}$ agar. $20 \mathrm{gm}$ dextrose in a conical flask and autoclaved at $121 \mathrm{c}$ under $15 \mathrm{psi}$ for 30 minutes. After autoclaved the media was kept few minutes for cool and added 25-30 drops of lactic acid then poured into sterile Petri plates.

\subsection{Preparation of CDA}

Carrot dextrose agar were prepared by $200 \mathrm{gm}$ carrot extract, $1000 \mathrm{ml}$ distilled water, $17 \mathrm{gm}$ agar, $20 \mathrm{gm}$ dextrose in a conical flask and autoclaved at $121 \mathrm{c}$ under 15 psi for 30 minutes. After autoclaved the media was kept few minutes for cool and added 25-30 drops of lactic acid then poured into sterile Petri plates.

\subsection{Preparation of Potato-Carrot Dextrose Agar (PCDA)} The combination of Potato-Carrot dextrose agar prepared by $100 \mathrm{ml}$ potato $+100 \mathrm{ml}$ carrot extract, $1000 \mathrm{ml}$ distilled water, $17 \mathrm{gm}$ agar, $20 \mathrm{gm}$ dextrose in a conical flask and autoclaved at $121 \mathrm{c}$ under $15 \mathrm{psi}$ for 30 minutes. After autoclaved the media was kept few minutes for cool and added 25-30 drops of lactic acid then poured into sterile petriplates.

\subsection{Isolation and Identification of Alternaria spp.}

The pathogen was isolated by tissue planting method and incubated at $25 \pm 1^{\circ} \mathrm{C}$ for 7 days. After incubation the fungus mycelia were examined under stereomicroscope (Model: Motic, SMZ-168) \& compound microscope (Model: Omano, OMTM-85) for identification of the pathogen. The fungus was identified following the keys of Eills[9] .

\subsection{Purification and preservation of the pathogen}

The pure culture of $A$. brassicae from the PDA was transferred to PDA slants and allowed to grow at $25 \pm 1^{\circ} \mathrm{C}$ for 7 days. After incubation PDA slants were preserved in refrigerator at $4^{0} \mathrm{C}$ for further study.

\subsection{Colony characters of Alternaria spp.}

Colony characters in terms of surface colour, colony shape, colony texture, zonation (surface and subsurface) and subsurface colour were studied.

\subsection{Morphological variability of Alternaria spp.}


All the isolates were studied for morphological variations. In terms of conidia color, shape, size, septation, was observed on PDA medium.

2.10 Effect of culture media on growth, spore production and time of sporulation

Mycelial discs of 7 days old culture of Alternaria spp. isolates were transferred to the center of PDA, CDA and PCDA and incubated at $25^{\circ} \mathrm{C}$ and $22 \pm 1^{\circ} \mathrm{C}$ and data were recorded on growth, spore production and time of sporulation. 3 replications were maintained for each isolates in a completely randomized design. The colony diameter was recorded on 2, 4, 6, 8, 10, 12, 14 days after inoculation.

\subsection{Data Analysis}

For cultural, morphological and the treatment means the data were statistically analyzed by Duncan's Multiple Range test (DMRT) with significance level at 5\% [13]. The package used for analysis was MSTAT-C version -88, developed by Michigan State University, Agricultural University of Norway [11].

\section{RESULTS}

3.1 Colony characters of isolates of Alternaria spp. on PDA

Variation was observed in colony characters of 10 isolates of A. brassicae like surface colour, shape, texture, zonation and subsurface colour are presented Table 2 and Figure 1.

3.2 Morphological variation of conidia of different isolates of Alternaria spp.

\subsubsection{Size of conidia of Alternaria spp. on PDA}

Remarkable variation was observed in length, breadth and beck size of conidia of different isolates of $A$. brassicae on PDA (Table 3). The length of conidia of different isolates varied from $41.56 \mu \mathrm{m}$ to $117.54 \mu \mathrm{m}$. The maximum mean length was recorded at $\mathrm{MYM}_{\mathrm{Ab}} 113.1 \mu \mathrm{m}$. The minimum length was recorded at isolates $\mathrm{GAZ}_{\mathrm{Ab}} 63.63 \mu \mathrm{m}$.

The breadth of conidia of different isolates varied from $10.34 \mu \mathrm{m}$ to $23.12 \mu \mathrm{m}$. The maximum mean breadth was recorded at $\mathrm{PAB}_{\mathrm{Ab}} 17.36 \mu \mathrm{m}$. The minimum mean breadth was recorded at $\mathrm{LAL}_{\mathrm{Ab}} 20.29 \mu \mathrm{m}$. The beak of conidia of different isolates varied from $16.78 \mu \mathrm{m}$ to $72.65 \mu \mathrm{m}$. The maximum mean beak was recorded at $\mathrm{PAB}_{\mathrm{Ab}} 43.26 \mu \mathrm{m}$. The minimum mean beak was recorded at $\mathrm{GAZ}_{\mathrm{Ab}} 24.84 \mu \mathrm{m}$.

\subsubsection{Conidial characteristics of Alternaria spp. on PDA}

All isolates were muriform. Colour of isolates of $A$.

brassicae varied from light brown to deep brown (Table 4). Isolates $\mathrm{NAT}_{\mathrm{Ab}}$ and $\mathrm{GAZ}_{\mathrm{Ab}}$ show light brown colour, $\mathrm{DHA}_{\mathrm{Ab}}, \mathrm{MYM}_{\mathrm{Ab}}, \mathrm{LAL}_{\mathrm{Ab}}, \mathrm{BOG}_{\mathrm{Ab}}$ and RAJ $\mathrm{Ab}_{\mathrm{Ab}}$ show brown

Table.3: Size of conidia of different isolates of Alternaria spp. on PDA

\begin{tabular}{|c|c|c|c|}
\hline Isolate & $\operatorname{Length}(\mu \mathrm{m})^{1}$ & $\operatorname{Breadth}(\mu \mathrm{m})^{1}$ & $\operatorname{Beak}(\mu \mathrm{m})^{1}$ \\
\hline DHA $_{A b}$ & $88.55 \mathrm{~d}$ & $18.12 \mathrm{~b}$ & $28.09 \mathrm{e}$ \\
\hline $\mathbf{G A Z}_{\mathrm{Ab}}$ & $63.63 \mathrm{e}$ & $18.09 \mathrm{~b}$ & $24.84 \mathrm{e}$ \\
\hline $\mathbf{M Y M}_{\mathrm{Ab}}$ & $113.1 \mathrm{a}$ & $18.56 \mathrm{ab}$ & $38.76 \mathrm{bc}$ \\
\hline $\mathbf{P A B}_{\text {Ab }}$ & $103.4 \mathrm{bc}$ & $17.36 \mathrm{~b}$ & $43.26 \mathrm{a}$ \\
\hline $\mathbf{R A N}_{\mathbf{A b}}$ & $99.33 \mathrm{bc}$ & $17.90 \mathrm{~b}$ & $37.19 \mathrm{c}$ \\
\hline $\mathbf{N A T}_{\mathbf{A b}}$ & $90.03 \mathrm{~d}$ & $17.87 \mathrm{~b}$ & $37.93 c$ \\
\hline $\mathbf{N A O}_{\mathbf{A b}}$ & $87.73 \mathrm{~d}$ & $20.17 \mathrm{a}$ & $25.98 \mathrm{e}$ \\
\hline $\mathbf{L A L}_{\mathbf{A b}}$ & $101.5 \mathrm{bc}$ & $20.29 \mathrm{a}$ & $38.95 \mathrm{bc}$ \\
\hline $\mathbf{B O G}_{\mathrm{Ab}}$ & $97.61 \mathrm{c}$ & $18.23 \mathrm{~b}$ & $41.89 \mathrm{ab}$ \\
\hline $\mathbf{R A} \mathbf{J}_{\mathbf{A b}}$ & $104.7 \mathrm{~b}$ & $19.12 \mathrm{ab}$ & $33.23 \mathrm{~d}$ \\
\hline $\begin{array}{l}\text { LSD } \\
(0.05)\end{array}$ & 6.82 & 1.82 & 3.47 \\
\hline CV (\%) & 4.22 & 5.75 & 5.82 \\
\hline
\end{tabular}

\begin{tabular}{|c|c|c|c|c|c|c|}
\hline \multicolumn{7}{|c|}{ Table.2: Colony Characters of different isolates of Alternaria spp. on PDA } \\
\hline \multirow[b]{2}{*}{ Isolates } & \multicolumn{2}{|c|}{ Colour } & \multirow{2}{*}{ Texture } & \multirow{2}{*}{$\begin{array}{l}\text { Colony } \\
\text { shape }\end{array}$} & \multicolumn{2}{|l|}{ Zonation } \\
\hline & Surface & Subsurface & & & Surface & Subsurface \\
\hline $\mathrm{DHA}_{\mathrm{Ab}}$ & $\begin{array}{l}\text { Olivacious } \\
\text { green }\end{array}$ & $\begin{array}{l}\text { Black center with } \\
\text { white surroundings }\end{array}$ & Cottony & Circular & No zonation & Zonation \\
\hline $\mathrm{GAZ}_{\mathrm{Ab}}$ & $\begin{array}{l}\text { Olivacious } \\
\text { green }\end{array}$ & $\begin{array}{l}\text { Black center with } \\
\text { pinkish surroundings }\end{array}$ & Cottony & Circular & Zonation & Zonation \\
\hline $\mathrm{MYM}_{\mathrm{Ab}}$ & Black & Brownish & Velvety & Circular & No zonation & Zonation \\
\hline $\mathrm{PAB}_{\mathrm{Ab}}$ & $\begin{array}{l}\text { Olivacious } \\
\text { green }\end{array}$ & $\begin{array}{l}\text { Black center with } \\
\text { pinkish surroundings }\end{array}$ & Cottony & Circular & No zonation & Zonation \\
\hline $\mathrm{RAN}_{\mathrm{Ab}}$ & Black & Black & Cottony & Circular & No zonation & No zonation \\
\hline $\mathrm{NAT}_{\mathrm{Ab}}$ & Black & Black center with & Cottony & Circular & Zonation & No zonation \\
\hline
\end{tabular}




\begin{tabular}{lllllll}
\hline \multicolumn{5}{c}{ white surroundings } & & \\
\hline $\mathrm{NAO}_{\mathrm{Ab}}$ & $\begin{array}{l}\text { Olivacious } \\
\text { green }\end{array}$ & Greenish black & Velvety & Circular & Zonation & No zonation \\
\hline $\mathrm{LAL}_{\mathrm{Ab}}$ & $\begin{array}{l}\text { Olivacious } \\
\text { green }\end{array}$ & Light brown & Velvety & Circular & No zonation & Zonation \\
\hline $\mathrm{BOG}_{\mathrm{Ab}}$ & Black & Black & Cottony & Circular & No zonation & No zonation \\
\hline $\mathrm{RAJ}_{\mathrm{Ab}}$ & $\begin{array}{l}\text { Olivacious } \\
\text { green }\end{array}$ & $\begin{array}{l}\text { Brownish green with } \\
\text { pinkish surroundings }\end{array}$ & Cottony & Circular & Zonation & Zonation \\
\hline
\end{tabular}

Table.4: Conidial characteristics of Alternaria spp.

\begin{tabular}{lllll}
\hline \multicolumn{1}{c}{ Isolates } & & & Septation (Range) & \\
\cline { 4 - 5 } & From & Colour & Horizontal & Vertical \\
\hline DHA $_{\mathbf{A b}}$ & Muriform & Brown & $5-9$ & $0-1$ \\
\hline GAZ $_{\mathbf{A b}}$ & Muriform & Light brown & $3-7$ & $0-2$ \\
\hline $\mathbf{M Y M}$ & Muriform & Brown & $5-7$ & $2-3$ \\
\hline PAB $_{\mathbf{A b}}$ & Muriform & Deep Brown & $5-7$ & $1-2$ \\
\hline RAN $_{\mathbf{A b}}$ & Muriform & Deep Brown & $5-7$ & $2-3$ \\
\hline $\mathbf{N A T}_{\mathbf{A b}}$ & Muriform & Light brown & $7-11$ & $2-3$ \\
\hline $\mathbf{N A O}_{\mathbf{A b}}$ & Muriform & Deep Brown & $5-8$ & $1-3$ \\
\hline $\mathbf{L A L}_{\mathbf{A b}}$ & Muriform & Brown & $7-9$ & $1-3$ \\
\hline BOG $_{\mathbf{A b}}$ & Muriform & Brown & $7-11$ & $0-3$ \\
\hline $\mathbf{R A J}_{\mathbf{A b}}$ & Muriform & Brown & $5-9$ & $1-2$ \\
\hline
\end{tabular}

colour. $\mathrm{PAB}_{\mathrm{Ab}}$. RAN $\mathrm{Ab}$ and $\mathrm{NAO}_{\mathrm{Ab}}$ show deep brown in colour. (Figure 2)

Variation in septation observed in isolates of A.brassicae. The horizontal septation varied from 3-7 to 7-11. The vertical septation varied from $0-1$ to $2-3$. The maximum horizontal septation observed isolates $\mathrm{BOG}_{\mathrm{Ab}}$ (7-11) and minimum septation observed in isolates $\mathrm{GAZ}_{\mathrm{Ab}}$. The maximum vertical (2-3) septation observed in isolates $\mathrm{MYM}_{\mathrm{Ab}}, \mathrm{RAN}_{\mathrm{Ab}}$ and $\mathrm{NAT}_{\mathrm{Ab}}$. The minimum vertical(0-1) septation observed in isolate $\mathrm{DHA}_{\mathrm{Ab}}$.

\subsection{Cultural variability of Alternaria brassicae}

\subsubsection{Radial mycelial growth of 10 isolates of Alternaria} spp. on PDA

Radial mycelial growth of different isolates of Alternaria spp. significantly varied on PDA (Table 5 and Plate 1). After 2 days of inoculation the maximum radial mycelial growth of $A$. brassicae $(30.50 \mathrm{~mm})$ was observed in $\mathrm{DHA}_{\mathrm{Ab}}$, followed by $\mathrm{PAB}_{\mathrm{Ab}}(27.00 \mathrm{~mm})$. The minimum radial mycelial growth $(14.67 \mathrm{~mm})$ was recorded in $\mathrm{NAO}_{\mathrm{Ab}}$ which was statistically similar to $\mathrm{GAZ}_{\mathrm{Ab}}(17.33 \mathrm{~mm})$.

After $4^{\text {th }}$ day, $6^{\text {th }}$ day, $8^{\text {th }}$ day, $10^{\text {th }}$ day and $12^{\text {th }}$ day of inoculation the maximum radial mycelial growth of Alternaria spp. were recorded in $\mathrm{DHA}_{\mathrm{Ab}}$ which were 48.33 $\mathrm{mm}, 64.00 \mathrm{~mm}, 79.93 \mathrm{~mm}, 89.33 \mathrm{~mm}$ and $90.00 \mathrm{~mm}$, respectively and the minimum radial mycelial growth were recorded in $\mathrm{NAO}_{\mathrm{Ab}}$ which was $33.50 \mathrm{~mm}$.

After 14 days of inoculation the maximum radial mycelial growth of Alternaria spp. was measured in $\mathrm{DHA}_{\mathrm{Ab}}$ which was $(90.00 \mathrm{~mm})$, followed by $\mathrm{PAB}_{\mathrm{Ab}}(88.33 \mathrm{~mm})$. The minimum radial mycelial growth was recorded in $\mathrm{NAO}_{\mathrm{Ab}}$ which was $(76.67 \mathrm{~mm})$ which was statistically similar to $\mathrm{MYM}_{\mathrm{Ab}}(79.67 \mathrm{~mm})$.

\subsubsection{Radial mycelial growth of 10 isolates of Alternaria spp. on CDA}

After 2 days of inoculation the maximum radial mycelial growth of Alternaria spp. $29.67 \mathrm{~mm}$ was measured in $\mathrm{NAT}_{\mathrm{Ab}}$, followed by $\mathrm{RAJ}_{\mathrm{Ab}}(28.67 \mathrm{~mm})$. The minimum radial mycelial growth was recorded in $\mathrm{GAZ}_{\mathrm{Ab}}(17.67 \mathrm{~mm})$ which was statistically similar to $\mathrm{MYM}_{\mathrm{Ab}}(19.17 \mathrm{~mm})$.

After $4^{\text {th }}$ days, $6^{\text {th }}$ days, $8^{\text {th }}$ days, $10^{\text {th }}$ day and $12^{\text {th }}$ days of inoculation the maximum radial mycelial growth of $A$. brassicae were measured in $\mathrm{NAT}_{\mathrm{Ab}}$ which was $49.17 \mathrm{~mm}$, $65.33 \mathrm{~mm}, 82.33 \mathrm{~mm}, 87.00 \mathrm{~mm}$ and $90.00 \mathrm{~mm}$ respectively and the minimum radial mycelial growth were recorded in GAZ $26.33 \mathrm{~mm}, 42.33 \mathrm{~mm}, 54.33 \mathrm{~mm}, 73.33$ $\mathrm{mm}$ and $77.67 \mathrm{~mm}$ respectively. 
After 14 days of inoculation the maximum radial mycelial growth of Alternaria spp. was measured in $\mathrm{NAT}_{\mathrm{Ab}}(90.00$ $\mathrm{mm}$ ), which was statistically similar to $\mathrm{RAJ}_{\mathrm{Ab}}$ which was $89.33 \mathrm{~mm}$. The minimum radial mycelial growth was recorded in $\mathrm{GAZ}_{\mathrm{Ab}}(83.67 \mathrm{~mm})$ which was statistically similar to $\mathrm{MYM}_{\mathrm{Ab}}(85.33 \mathrm{~mm})$.
3.3.3 Radial mycelial growth of 10 isolates of Alternaria spp. on PCDA

After 2 days of inoculation the maximum radial mycelial growth of Alternaria spp. was measured in $\mathrm{RAJ}_{\mathrm{Ab}}$ which was $(33.17 \mathrm{~mm})$ which was statically similar to $\mathrm{RAN}_{\mathrm{Ab}}$ (31.83 $\mathrm{mm})$. The minimum radial mycelial growth was recorded in $\mathrm{NAO}_{\mathrm{Ab}}$ which was $(20.33 \mathrm{~mm})$ which was statistically similar to $\mathrm{MYM}_{\mathrm{Ab}}(23.33 \mathrm{~mm})$.

Table.5: Radial mycelial growth of different isolates of Alternaria spp. at different days after incubation onPDA

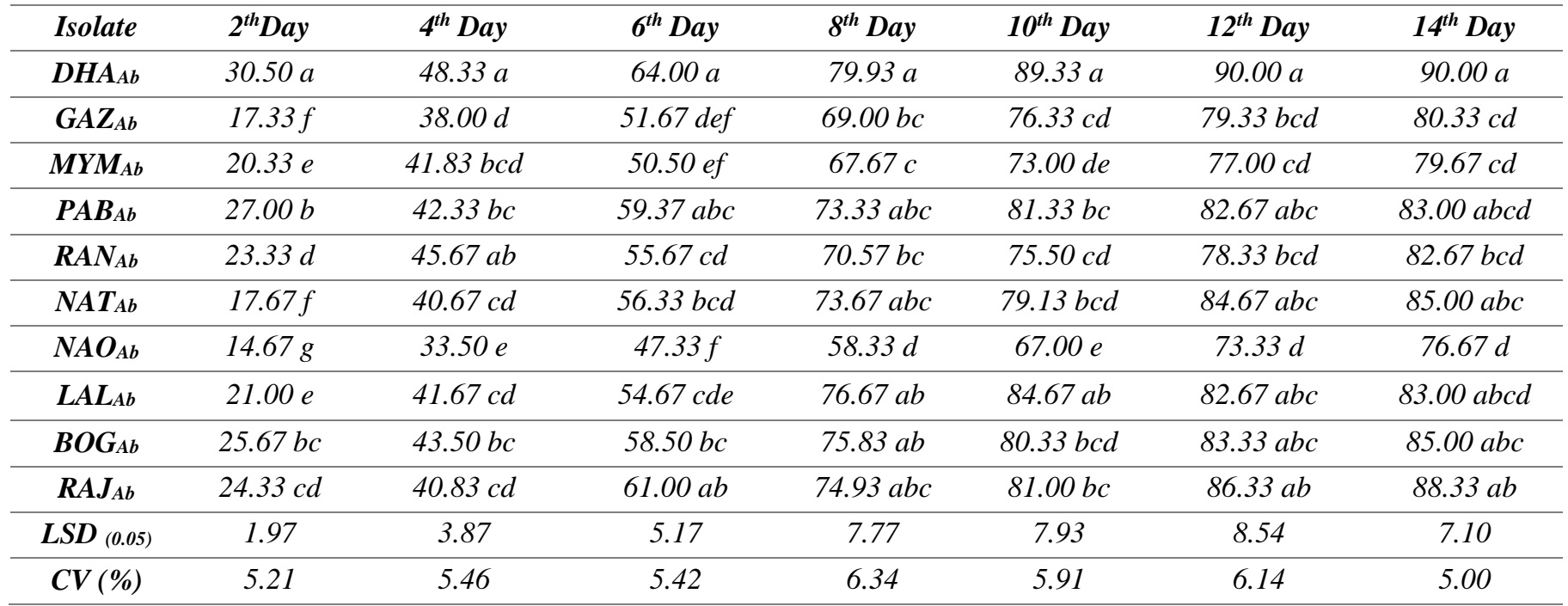

Table.6: Radial mycelial growth of different isolates of Alternaria spp. at different days after incubation on CDA

\begin{tabular}{|c|c|c|c|c|c|c|c|}
\hline Isolate & $2^{\text {th }}$ Day & $4^{\text {th }}$ Day & $6^{\text {th }}$ Day & $8^{\text {th }}$ Day & $10^{\text {th }}$ Day & $12^{\text {th }}$ Day & $14^{\text {th }}$ Day \\
\hline DHAAb $_{A}$ & $25.83 \mathrm{c}$ & $42.67 \mathrm{~b}-\mathrm{d}$ & $53.67 \mathrm{~cd}$ & 64.83 ef & 77.67 bc & 80.00 de & 86.67 ab \\
\hline $\mathbf{G A Z}_{\mathbf{A b}}$ & $17.67 \mathrm{e}$ & $26.33 \mathrm{f}$ & $42.33 \mathrm{f}$ & $54.33 \mathrm{~g}$ & $73.33 \mathrm{c}$ & $77.67 \mathrm{e}$ & 83.67 b \\
\hline $\mathbf{P A B}_{\mathrm{Ab}}$ & $26.67 \mathrm{bc}$ & $43.00 \mathrm{~b}-\mathrm{d}$ & 58.67 b-d & $72.67 \mathrm{~b}-\mathrm{d}$ & $81.67 \mathrm{ab}$ & 85.33 a-d & $87.33 \mathrm{ab}$ \\
\hline $\mathbf{R A N} \mathbf{N}_{\mathbf{A b}}$ & $22.00 \mathrm{~d}$ & $38.83 \mathrm{~d}$ & 53.17 de & 69.77 de & $81.67 \mathrm{ab}$ & 82.67 b-e & $88.33 \mathrm{ab}$ \\
\hline $\mathbf{L A L}_{\mathbf{A b}}$ & $26.00 \mathrm{c}$ & $42.00 \mathrm{~cd}$ & $60.67 \mathrm{ab}$ & 75.33 b-d & 76.67 bc & 81.33 c-e & $86.33 \mathrm{ab}$ \\
\hline BOG $_{A b}$ & 27.33 a-c & $46.50 \mathrm{ab}$ & $61.67 \mathrm{ab}$ & 76.33 a-c & 82.33 ab & 86.67 a-c & 88.67 ab \\
\hline $\mathbf{R A} \mathbf{J}_{\mathbf{A b}}$ & $28.67 \mathrm{ab}$ & 44.33 bc & $63.33 \mathrm{ab}$ & $78.33 \mathrm{ab}$ & 85.33 a & 88.33 ab & 89.33 ab \\
\hline $\operatorname{LSD}_{(0.05)}$ & 2.36 & 4.35 & 5.55 & 6.49 & 7.63 & 5.82 & 6.28 \\
\hline
\end{tabular}

Table.7: Radial mycelial growth of different isolates of Alternaria spp. at different days after incubation on PCDA

\begin{tabular}{cccccccc}
\hline Isolate & 2th Day & 4th Day & 6th Day & 8th Day & 10th Day & 12th Day & 14th Day \\
\hline DHAAb & $26.67 \mathrm{bc}$ & $45.20 \mathrm{~cd}$ & $61.33 \mathrm{~b}$ & $75.67 \mathrm{ab}$ & $85.00 \mathrm{ab}$ & $88.00 \mathrm{a}-\mathrm{c}$ & $89.00 \mathrm{ab}$ \\
\hline GAZAb & $26.67 \mathrm{bc}$ & $45.20 \mathrm{~cd}$ & $62.30 \mathrm{ab}$ & $78.27 \mathrm{a}$ & $84.20 \mathrm{ab}$ & $87.67 \mathrm{a}-\mathrm{c}$ & $88.00 \mathrm{ab}$ \\
\hline MYMAb & $23.33 \mathrm{~cd}$ & $42.33 \mathrm{de}$ & $52.33 \mathrm{c}$ & $69.33 \mathrm{bc}$ & $77.00 \mathrm{bc}$ & $81.67 \mathrm{c}$ & $85.33 \mathrm{c}$ \\
\hline
\end{tabular}




\begin{tabular}{cccccccc}
\hline PABAb & $29.67 \mathrm{ab}$ & $50.00 \mathrm{a}-\mathrm{c}$ & $63.50 \mathrm{ab}$ & $78.33 \mathrm{a}$ & $85.33 \mathrm{ab}$ & $88.67 \mathrm{ab}$ & $89.33 \mathrm{ab}$ \\
\hline RANAb & $31.83 \mathrm{a}$ & $46.33 \mathrm{~b}-\mathrm{d}$ & $63.00 \mathrm{ab}$ & $76.00 \mathrm{a}$ & $83.33 \mathrm{bc}$ & $86.33 \mathrm{a}$ & $89.67 \mathrm{ab}$ \\
\hline NATAb & $24.33 \mathrm{c}$ & $39.67 \mathrm{e}$ & $64.83 \mathrm{ab}$ & $76.10 \mathrm{a}$ & $84.83 \mathrm{ab}$ & $89.67 \mathrm{ab}$ & $90.00 \mathrm{a}$ \\
\hline NAOAb & $20.33 \mathrm{~d}$ & $33.83 \mathrm{f}$ & $48.33 \mathrm{c}$ & $64.67 \mathrm{c}$ & $70.67 \mathrm{c}$ & $74.67 \mathrm{~d}$ & $79.00 \mathrm{~d}$ \\
\hline LALAb & $31.50 \mathrm{a}$ & $46.33 \mathrm{~b}-\mathrm{d}$ & $65.33 \mathrm{ab}$ & $78.67 \mathrm{a}$ & $83.00 \mathrm{ab}$ & $85.33 \mathrm{a}-\mathrm{c}$ & $87.33 \mathrm{bc}$ \\
\hline BOGAb & $31.00 \mathrm{a}$ & $50.67 \mathrm{ab}$ & $66.33 \mathrm{ab}$ & $79.00 \mathrm{a}$ & $84.33 \mathrm{ab}$ & $88.67 \mathrm{ab}$ & $90.00 \mathrm{a}$ \\
\hline RAJAb & $33.17 \mathrm{a}$ & $54.83 \mathrm{a}$ & $68.17 \mathrm{a}$ & $80.27 \mathrm{a}$ & $88.33 \mathrm{a}$ & $90.00 \mathrm{a}$ & $90.00 \mathrm{a}$ \\
\hline LSD (0.05) & 3.62 & 5.19 & 6.05 & 6.64 & 8.86 & 6.41 & 2.66 \\
\hline CV (\%) & 7.65 & 6.71 & 5.77 & 5.16 & 6.27 & 4.39 & 1.78 \\
\hline
\end{tabular}

After $4^{\text {th }}$ days, $6^{\text {th }}$ days, $8^{\text {th }}$ days, $10^{\text {th }}$ days and $12^{\text {th }}$ days of inoculation the maximum radial mycelial growth of $A$. brassicae $54.83 \mathrm{~mm}, 68.17 \mathrm{~mm}, 80.27 \mathrm{~mm}, 88.33 \mathrm{~mm}$ and $90.00 \mathrm{~mm}$ were measured in $\mathrm{RAJ}_{\mathrm{Ab}}$ and the minimum radial mycelial growth were recorded in $\mathrm{NAO}_{\mathrm{Ab}} 33.83 \mathrm{~mm}$, $48.33 \mathrm{~mm}, 64.67 \mathrm{~mm}, 70.67 \mathrm{~mm}$ and $74.67 \mathrm{~mm}$.

After 14 days of inoculation the maximum radial mycelial growth of Alternaria spp. was measured in $\mathrm{RAJ}_{\mathrm{Ab}} 90.00$ $\mathrm{mm}$, which was statistically similar to $\mathrm{BOG}_{\mathrm{Ab}}$ and $\mathrm{NAT}_{\mathrm{Ab}}($ $90.00 \mathrm{~mm}$ ). The minimum radial mycelial growth was recorded in $\mathrm{NAO}_{\mathrm{Ab}}(79.00 \mathrm{~mm})$ proceeded by $\mathrm{MYM}_{\mathrm{Ab}}$ $(85.33 \mathrm{~mm})$.

\section{DISCUSSION}

A laboratory examination was carried out at Plant Pathology Laboratory of Oil seed Research Center, BARI, Joydevpur, Gazipur to find out morphological and physiological variation among ten different isolates of Alternaria spp. isolated from mustard leaf having typical symptoms of Alternaria blight.

Leaves of mustard having typical symptoms were collected from ten different location of Bangladesh and causal organisims were isolated on PDA medium. All the isolates produced light brown to deep brown murifrom conidia with beak. This finding was supported by previous findings [18] . They were also found murifrom conidia which were brownish black. Some researcher worked with Alternaria spp. and found murifrom, obclavate conidia with brownish black [28].

All 10 isolates showed variations in respect of their cultural and morphological characteristics on different media. In respect of cultural characteristics, the isolates of Alternaria spp. showed variation in mycial growth, colony

color, shape, textures, subsurface color, zonation conidia production and sporulation time.

Remarkable effect of different culture media on radial mycelia growth was observed in Alternaria spp..Significant variation was found in colony color of A. brassicae on PDA medium. Most of the colony color of the isolates were olivacious green to black. The results are partially agreement with [33] who found that the colony color of $A$. mali isolated from apple was light to dark olivacious with greenish or brownish tinge. In case of A.alternata isolated from ribben plants colony colour black to olivaceous-black or grayish colour on PDA medium was found [24]. Thirty two isolates of $A$ brassicicola for colony color and radial growth were observed by [6]. Colony colour of $A$. brassicicola varied from olive green to dark olivacious black on PDA.

All the isolates of Alternaria spp. colony had circular shaped. The results are in agreement with [38] were identified its morphological and cultural characters of A.brassicae isolates from four different locations, colonies of all the isolates were circular in shape.The colony shape of A.solani isolated from tomato plants were found circular margin with smooth surfaced colony[31]. The entire isolates colony had cottony and velvety texture on PDA medium. The results are in agreement with [3] examined 308 isolates of Alternaria spp. colonies generally had a cottony texture on group 4. Alternaria blotch, causal organism A. mali, colonies varied in their cultural behavior ranging from velvety to cottony [33]. Remarkable variation was observed on spore production and sporulation time on different media and temperature. Potato Carrot Media are found suitable for spore production and sporulation time for maximum isolate followed by CDA and PDA. This result was supported by the [23] found potato carrot broth are suitable for sporulation and spore production A. brassicae. Variation were found in mycial growth, sporulation in different nutrient media like Potato Dextrose Agar, Cauliflower Agar medium and Carrot Potato Agar good for 32 isolates of $A$. brassicae[33].

Variations were observed in accordance with length, breadth and beck on different isolates of $A$. brassicae on PDA media. The length of conidia of different isolates 
varied from $41.56 \mu \mathrm{m}$ to $117.54 \mu \mathrm{m}$. The breadth of conidia of different isolates varied from $10.34 \mu \mathrm{m}$ to $23.12 \mu \mathrm{m}$. The beck of conidia of different isolates varied from $16.78 \mu \mathrm{m}$ to $72.65 \mu \mathrm{m}$. The horizontal septation varied from 3-7 to 7 11. The vertical station varied from $0-1$ to $2-3$. This result are partially supported with [28] define $A$. brassicae length of conidia varied from $96 \mu \mathrm{m}-114 \mu \mathrm{m}$, breadth varied from $17 \mu \mathrm{m}-24 \mu \mathrm{m}$ and beck length varied from $45 \mu \mathrm{m}-65 \mu \mathrm{m}$ and transverse and longitudinal septation varied from 10-11 and 0-6 respectively. 322 isolates of A. brassicae variation was recorded among conidial length, breadth and beak length which range of 51.4-481.2 $\mu \mathrm{m}, 6.9-36.0 \mu \mathrm{m}$ and 16.3 - $266.9 \mu \mathrm{m}$ respectively [16]. Average numbers of horizontal septa were 9.7, vertical septa were 0.8 . The horizontal septation of 5 different isolates of A.brassicae varied from 4-13 and vertical from 0-6[33]. 23 isolates of A. brassicae were collected and found maximum length of conidia ranged from $150-122 \mu \mathrm{m}$ with 8 - 9 transverse and 2 vertical septation [27] Eight isolates of A. solani were examined [25] and found average conidial size $(\mathrm{L} \times \mathrm{B})$ was $42.18 \times 15.18 \mu \mathrm{m}$ and beck size was $13.10 \mu \mathrm{m}$. In ten isolates of A. macrospora size of conidia ranged from 20.81-56.23 x 9.2- 27.10 $\mu \mathrm{m}$ with $1-6$ transverse and $0-4$ longitudinal septa were found [14]. ten isolates collected by[26] of A. alternata the length and width of conidia were varied from $30.99-42.47 \mu \mathrm{m}$ and 11.90-17.37 $\mu \mathrm{m}$ respectively. All isolates produced both beaked and unbeaked conidia. The beak length of conidia varied from 18.7-23.81 $\mu \mathrm{m}$. Alternaria blotch, causal organism A. mali 21 isolates of $A$. mali were collected from different locations. Average conidial size ranged from 21.36 to 31.74 x 8.34 to $14.48 \mu \mathrm{m}$. Among the isolates of A.mali size of conidia 19-50 $\mu \mathrm{m} \times 5-9 \mu \mathrm{m}$ in nature and $20-59 \mu \mathrm{m} \times 8-13$ $\mu \mathrm{m}$ in culture, with 3-8 transverse septa and usually no longitudinal septa or only 1 longitudinal septa were found [33].

\section{CONCLUSION}

Rapeseed Mustard (Brassica spp.) is the principal oilproducing crop of Bangladesh and Alternaria leaf blight caused by Alternaria brassicae, is one of the major disease of rapeseed mustard. This research was conducted to find out existence of physiological races of Alternaria spp. causing Alternaria leaf blight of mustard on the basis of cultural and morphological aspects. The experiment was laid out in the completely randomized design with three replications. Ten isolates of Alternaria spp. were collected from ten different mustard growing districts of Bangladesh. Three different media and two different temperatures were used to measure growth and development of Alternaria spp..

All the 10 isolates showed variation in the terms of cultural and morphological characteristics. Among three different culture media, potato carrot agar medium at $25^{\circ} \mathrm{C}$ showed the best performance in the terms of radial mycelial growth. Colour of the colonies of Alternaria spp. showed variation among ten isolates. Olivacious green to black color colony developed on PDA medium. All the isolates produced Circular colony and the texture were cottony to velvety. All isolates showed compact type compactness. Variation also observed between surface and sub surface colour. Surface colour varied from light brown to deep brown. Subsurface colour varied from light brown to black and pinkish. Zonation was present both surface and subsurface in some isolates and some isolates showed no zonation on both side. Effect of media on sporulation significantly differed among the isolates. The highest number of conidia production was recorded 48.17 to $59.79 \times 10^{6} / \mathrm{ml}$ was counted $\mathrm{RAJ}_{\mathrm{Ab}} \mathrm{On}$ Potato Carrot media at $25^{\circ} \mathrm{C}$ temperature. Of all the isolates of Alternaria spp. with maximum in isolate $\mathrm{RAJ}_{\mathrm{Ab}}$ and minimum in $\mathrm{NAO}_{\mathrm{Ab}}$. Temperature showed an influence on sporulation. (Data not shown).

Effect of media on sporulation time differed significantly among the isolates. The minimum days (4 days) required for sporulation in PCDA followed by CDA.

Remarkable variation among different Alternaria spp. isolates were observed in length, breadth and beak size of the conidia. The conidial length varied within a range of $41.56 \mu \mathrm{m}$ to $117.54 \mu \mathrm{m}$ and the breadths were varied from $10.34 \mu \mathrm{m}$ to $23.12 \mu \mathrm{m}$. All isolates were muriform and deep brown to light brown in colour with a beak length of 16.78 $\mu \mathrm{m}$ to $72.65 \mu \mathrm{m}$.

On the basis of the above results and discussion it can be summarized that- variability exists in the pathogen of alternaria leaf blight caused by Alternaria spp. prevailing in the rapeseed mustard growing areas of Bangladesh. Potato Carrot agar medium and $25^{\circ} \mathrm{C}$ temperature were appeared to be the best medium and temperature respectively for the mycelial growth and sporulation of this fungal pathogen. More research should be conducted on molecular characterization of this isolates to find out the phylogenetic relationship.

\section{ACKNOWLEDGEMENTS}

This research was partially supported by National Science and technology (NST) Fellowship 2015-2016 funded by Ministry of Science and Technology, Govt. of the People`s Republic of Bangladesh. 


\section{REFERENCES}

[1] Aneja J. K. and Agnihotri A., (2013), Alternaria blight of oilseed brassicas: epidemiology and disease control strategies with special reference to use of biotechnological approaches for attaining host resistance. J. of Oils.Bras. , 4(1):1-10.

[2] Anju M, Rajib R and Jagatpati T;(2013); Alternaria pathogenicity and its strategic controls; Res. J. of Biol.; 1: 01-09.

[3] Barry M. Pryor and Themis J. Michailides, (2002), Morphological, Pathogenic, and Molecular Characterization of Alternaria Isolates Associated with Alternaria Late Blight of Pistachio, Phytopah, 92(4), 406-416.

[4] BBS, (2015). Year Book of Agricultural Statistics of Bangladesh, 2014-15. Statistics Division, Ministry of Planning, Dhaka.

[5] Chand G and Chandra K. K.(2014), Symptomological, Cultural and Molecular Variability of Alternaria brassicicola Leaf Spot in BroccoliI (Brassica oleracea var. Italica L.), Int J Pharm Bio Sci; 1 5(2), (B) : 680 688.

[6] Deep. S, Sharma P., Behera N and Chowdappa $\mathrm{P},(2014)$,Diversity in Indian Isolates of Alternaria brassicicola(Schwein) Wiltshire Causing Black Leaf Spot Disease in Cauliflower, Plant Pathol J., 13(4):232245.

[7] Degenhardt K. J., Sxonopeo W. P., and Kondra Z. P. ( 1974), Effects of Alternaria Black spot on Yield Oil content and Protein content of Rapeseed. Can. J. Plant Sci. 54 (4): 795-799.

[8] Duczek, L. J., Seidle, E., Reed, S. L., Sutherland, K. A., Rude, S. V. and Rimmer, S. R. (1999). Effect of swathing on alternaria black spot in Brassica rapa canola in Saskatchewan. Can. J. Plant Sci. 79: 299-302.

[9] Ellis.M.B,(1971),Dematiaceous Hyphomycetes, Commonwealth Mycological Inistitute,Kew,Surry,CABI Publishing,Edition-1,pp 482.

[10]Fakir, G.A. (2008), Development of model for Alternaria leaf blight of Mustard in Bangladesh. APM workshop Held on 11-14 Feb at Dhaka, Bangladesh Science Foundation. Uttara, Dhaka. pp44.

[11] Freed R.D, Scott .D.E, (1986). MSTATC Crop and Soil Science Department, Michigan State University, MI, USA.

[12] Ghasemi M., Aghajani M. A., Faraji A. and Nejad M. R.S., (2013), Relationship Between Incidence AND Severity of Alternaria Blight Disease On Different
Species of Brassicae in Gonbad Region, Iran. J. Plant Path., 49(1), 17-19.

[13] Gomez. K. A, Gomez A .A (1986). Statistical Procedure for Agricultural Research (2nd edn.). International Rice Research Institute, A Willey-Inter- Science, Publication pp. 28-192.

[14] Jadhav B.M., PeraneR.R., Kale A.A. and Pawar N.B., (2011), Morphological, pathological and molecular variability among Alternaria macrospora isolates causing leaf blight of cotton, Indian Phytopath. 64 (3): 254-257.

[15]Jha P, Kumar M, Meena PD and Lal H C, (2013), Dynamics and management of Alternaria blight disease of Indian mustard (Brassica juncea) in relation to weather parameters, J. of Oils. Bras., 4(2): 66-74.

[16] Kaur S, Singh G and Banga S S. ( 2007). Documenting variation in Alternaria brassicae isolates based on conidial morphology, fungicidal sensitivity and molecular profile. (in) Proceeding of the 12th International Rapeseed Congress, 26-30 March, Wuhan, China 4: pp 87-89.

[17] Khan M.M. (2011), Alternaria blight of mustard, a real farmer headache: morpho - physio variations and its cost effective management, lap lambert academic publishing. Isbn-13: 978-3845437187, pp-100.

[18] Kumar A, Katoch A, Sharma P, Kumari V and Kumar A ,2014), Pathogenic and genetic variability in Alternaria brassicae infecting rapeseed-mustard and evaluation of resistance sources, Indian Phytopath. 67 (3) : 257-262.

[19] Kumar D, Maurya N, Bharati Y .K., Kumar A., Kumar K, Srivastava K, Chand G, Kushwaha C, Singh S.K,Mishra R. K and Kumar A,(2014), Alternaria blight of oilseed Brassicas: A comprehensive Review, Afri. J. of Microbiol. Res., 8 (30):2816-2829.

[20] Mathpal P., Punethav H., Tewari A.K. and Agrawal S., (2011), Biochemical defense mechanism in rapeseedmustard genotypes against Alternaria blight disease, $J$. of Oils. Bras., 2 ( 2): 87-94.

[21] Meena P D, Gupta R, Rani A, Sharma P and Singh D, (2016), Effect of summer temperatures on survival of Alternaria brassicae in infected Indian mustard (Brassica juncea) debris and thermal death point variations amongst geographical isolates, J. Oils. Bras., 7 ( 1) : 45-51.

[22] Meena P.D, Awasthi R.P, Chattopadhyay. C, Kolte S.J and Arvind k, (2010), Alternaria blight: a chronic disease in rapeseed-mustard, J. of Oils. Bras., 1( 1), 111. 
[23] Meena P.D, Gupta R, Sharma P, Rani A, Jha1 A .K, Meena H.S, Bala M, Singh D and Chowdappa P, (2016), Variability and growth response among Alternaria brassicae isolates causing black spot disease in oilseed Brassica, J. of Oils.Bras., 7 (2) : 126-138.

[24] Muthukumar A .and Venkatesh A, (2013), A new record of leaf blight of ribben plant caused by Alternaria alternata inIndia, J.on New Biol.Rep., 2(3): 228-230.

[25] Nikam P. S, Suryawanshi A. P and Chavan A.A, (2015), Pathogenic, cultural, morphological and molecular variabilityof eight isolates of Alternaria solani causing early blight of tomato, Afri. J. Of Biotech, 14(10): 872877.

[26] Ramjegathesh R. and Ebenezar E.G. (2012). Morphological and Physiological Characters of Alternaria alternata Causing Leaf Blight Disease of Onion. Inter. J. of Plant Path. 3: 34-44.

[27]Saha, S., Garg, R., Venkataravanappa, Mishra V. P. K., Rai A. B. and Singh P. R.(2016). Molecular and Cultural Characterization of Alternaria brassicae Infecting Cauliflower in Uttar Pradesh, India. Proc. Natl. Acad. Sci., India, Sect. B Biol. Sci. 86: 485.

[28] Saharan GS, Naresh Mehta and Meena PD. (2016).Alternaria blight of crucifers: Biology, Ecology and Management. Springer Verlag, Singapore, pp 54, eBook ISBN 978-981-10-0021-8, Edition (1).

[29] Selvamani R., Pandian R.T.P. and Sharma P., (2014), Role of weather on Alternaria leaf spot development inCrucifers, Indian Phytopath. 67 (3) : 285-290.

[30] Sharma M, Deep S, Bhati D.S, Chowdappa. P, Selvamani. R and Sharma P.(2013). Morphological, cultural, pathogenic and molecular studies of Alternaria brassicae infecting cauliflower and mustard in India. Afri. J. of Biotec. 7( 26):3351-3363.

[31] Singh M, Singh H.K., Shiwangi, Maurya M, (2014), Morphological, Physiological and cultural variability in
Alternaria brassicae isolates of Indian mustard, Brassicae juncea L. Czern \& Coss. collected from different Agro climatic regions of India, Euro. J. of Biotec.y and Biosci., 3( 6): 33-37.

[32] Singh M.,. Singh H. K, Singh R. B., Shiwangi and Abhishek,(2015), Cultural and pathogenic variability in Alternaria brassicae isolates of Indian mustard [Brassica juncea (L.) Czern. and Coss] collected from different agro-climatic regions of India, Res. Environ. Life Sci.8(2) :281-286.

[33] Sofi T. A., Beig M A, Dar Gh H., Ahmad M, Hamid A, Ahangar F. A., Padder B. A. and Shah M. D.,(2013), Cultural, morphological, pathogenic and molecular characterization of Alternaria mali associated with Alternaria leaf blotch of apple, Afri. J. of Biotec. 12(4), 370-381.

[34] Soo-Sang H., Kwon Mi., Kim.B K, Han H K, and Nam Y G, (2016) Alternaria Leaf Spot Caused by Alternaria mali on Black Chokeberry in Korea, Res. Plant Dis. 22(1): 50-54.

[35] Tanya R. Marak, Ambesh .S.B and Srikanta. D. (2014). Cultural, Morphological and Biochemical Variations of Alternaria solani Causing Diseases on Solanaceous Crops, The Bioscan: 9(3): 1295-1300.

[36] Thakur P.R.(1999).Pathogen diversity and plant disease management. Indian Phytopath.52(1):1-9.

[37] Verma, P.R. and Saharan, G.S. (1994). Monograph on Alternaria diseases of crucifers. Saskatoon Research Centre Technical Bulletin 1994-6E, Agriculture and AgriFood Saskatoon.

[38] Yadav S.P, Kumar S, Prasad R, Upadhyay H and Bansal M, (2016), Identification of morphological, cultural and pathogenic variability of Alternaria brassicae causing Alternaria blight of Indian mustard (Brassic juncea), Indian Phytopath, 69( 1): 102-104. 


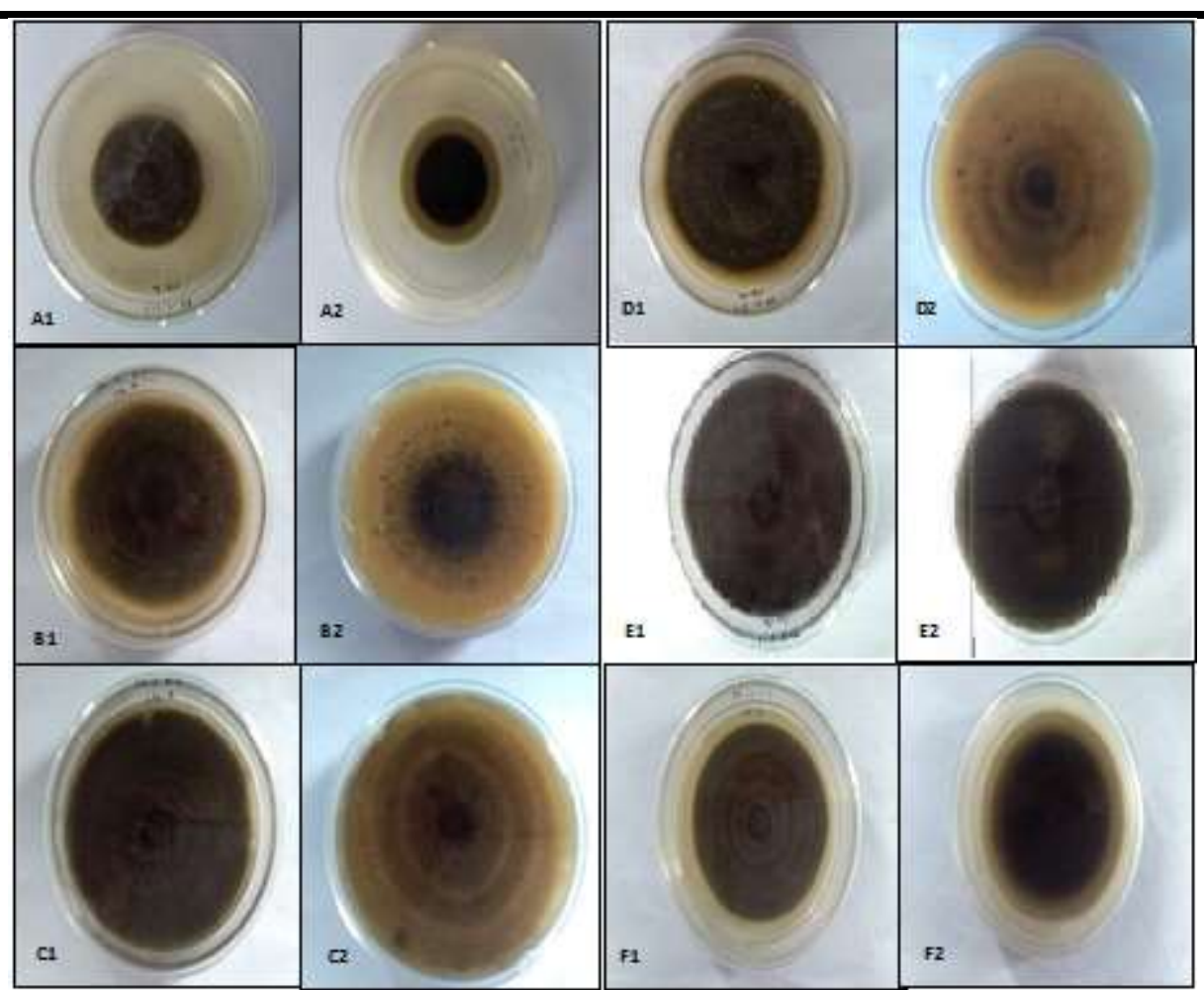

Plate.1: Colony charecters of different isolates of A. Brassicae on PDA media 1. Surface 2. Sub-surface
A. $D H A_{A b}$
B. $G A Z_{A b}$
C. $M Y M_{A b}$
D. $P A B_{A b}$ E. RAN $N_{A b}$
F. $N A T_{A b}$

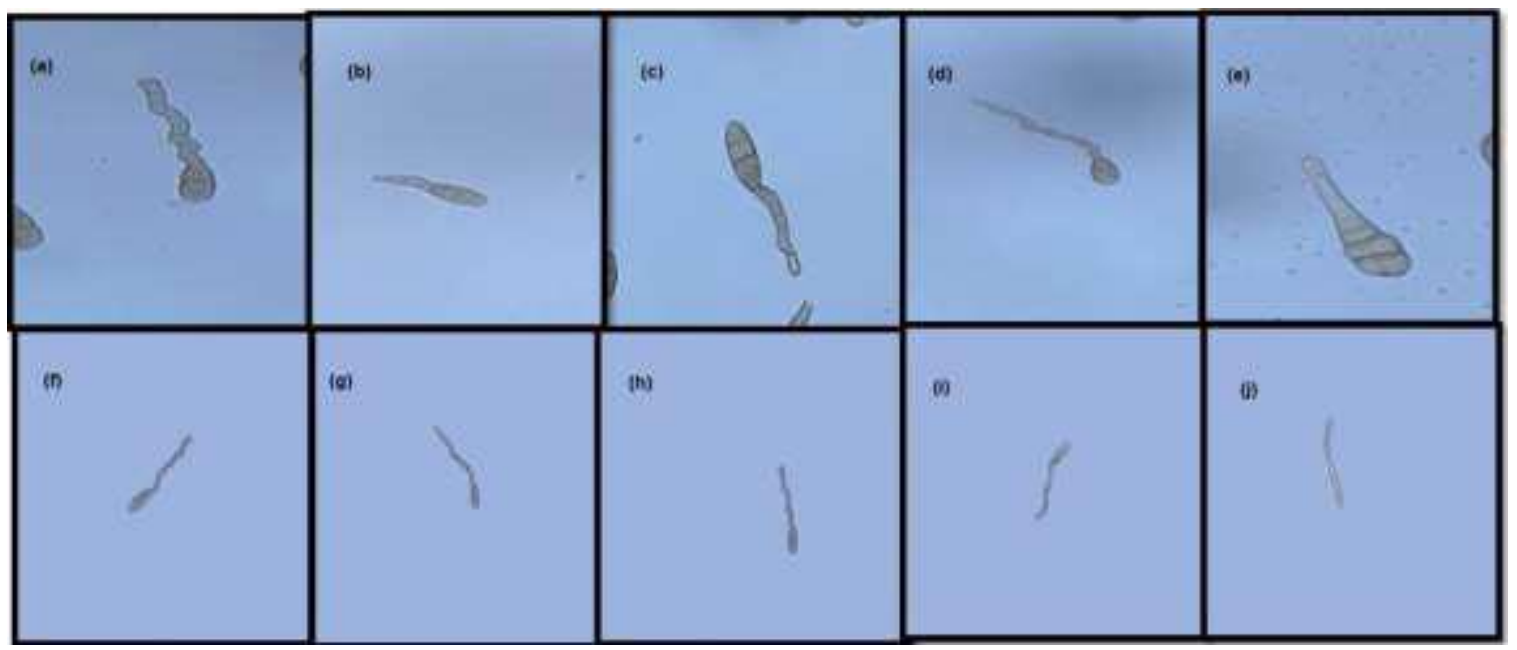

Plate.2: Conidial characteristics of A.brassicae $\quad$ A. DHA $A$ Ab $\quad$ BAZ $Z_{A b} \quad$ C. $M Y M_{A b}$ $\begin{array}{llll}\text { D. } P A B_{A b} & \text { E. RAN } & \text { F. NAT } & \text { G. } N A O_{A b} \text { H. LAL } \\ A b & \text { I. BOG } & \text { J } & \text { J. RAJ } \\ A b\end{array}$ 